\title{
DE WOELRAT OF WATERRAT (ARVICOLA AMPHIBIUS L.)
}

Dit dier (zie plaat I) heeft wel is waar ook vroeger hier te lande veel schade aangericht, en kan met name in sommige waterrijke streken (o.a. aan den Langendijk en in Aalsmeer) sedert onheugelijke tijden het schadelijkste zoogdier worden genoemd; maar nu heeft het zich in de laatste paar jaren op zoo vele plaatsen van ons land in sterke mate vermeerderd, dat het eene meer algemeene plaag is geworden, en wel eene plaag, waarmee èn de landbouwer, èn de oofteler, èn de boomkweeker èn de groenteteler èn ook de boschbouwer te maken hebben.

De gewone benaming "waterrat" is eigenlijk een ongelukkige Nederlandsche naam: een naam, die geregeld aanleiding geeft tot verwarring.

Het woord "waterrat" toch doet denken aan een zoogdier van den bouw en den vorm van eene muis, maar tamelijk wat grooter, levende in de buurt van het water. Nu is het wel waar, dat het door ons bedoelde dier zeer vaak in grooten getale aan den kant van het water wordt aangetroffen en dat het zich gaarne te water begeeft; maar aan den anderen kant treft men het toch ook zeer veel in niet minder groot aantal op hooge en droge, ver van rivieren, kanalen en slooten, van meren en plassen verwijderd gelegen streken aan. Vindt iemand het dier in eene zoodanige streek, dan klinkt hem de naam "waterrat” al heel vreemd in de ooren. 
Aan den anderen kant is er eene "rat", die wel is waar evenmin uitsluitend aan den waterkant wordt aangetroffen, maar toch ook dáár veel voorkomt, die insgelijks gaarne te water gaat en uitstekend zwemt, n.l. de bruine rat (Mus decumanus L.), en die door velen geregeld met den naam "waterrat" bestempeld wordt.

Om verwarring te voorkomen, is het dus beter, voor onze Arvicola amphibius den naam „woelral" te gebruiken: een naam ("Wühlratte"), dien men in Duitsche werken nog al eens vaak leest, hoewel ook de naam "Wasserratte" toch veel in Duitschland wordt gebruikt en verder de benamingen "Wühlmaus" en "Mollmaus" nog al eens worden gehoord (de laatste benaming in Westfalen).

In de Graafschap en bij Werkhoven (Utrecht), misschien nog in andere gedeelten van ons land, duidt de bevolking het bedoelde knaagdier meestal aan met den naam "hamster". Herhaaldelijk hoorde ik in de genoemde streken spreken van de aldaar zoo veel voorkomende "hamsters"; ik verzocht, zoodra de gelegenheid zich daartoe mocht aanbieden, mij eens zoo'n "hamster" toe te zenden, en telkens bleek het eene waterrat te zijn. Trouwens den waren hamster kent men hoofdzakelijk als een bewoner van een stevigen, samenhangenden, klei- of leemachtigen bodem; bij ons te lande schijnt zij nergers anders voor te komen dan op den lössgrond van Zuid-Limburg.

Ten einde er toe mee te werken, dat voor 't vervolg verwarring worde voorkomen, zal ik in het verdere verloop van dit artikel den naam "waterrat" niet meer gebruiken, maar in plaats daarvan steeds van de "woelrat" spreken, welke naam spoedig genoeg het burgerrecht hier te lande kan krijgen.

Het dier behoort tot de zoogenaamde „woelmuizen”. Waardoor deze zich van de "ware muizen" onderscheiden, kan men nalezen in het $17 \mathrm{e}$ deel van dit Tijdschrift, bl. 62-64.

De "woelrat" is zonder den staart $15-20$ c.M. lang, terwijl 
de staart eene lengte van 6-10 c.M. heeft. De ooren bereiken hoogstens $1 / 4$ van de lengte van den kop, en zijn onder de vacht verscholen. De voorrand van het oor is aan den buitenrand tot aan het midden lang behaard. Aan de binnenvlakte van het oor bevindt zich, van de basis van den buitenrand uitgaande, naar de ooropening toe een dicht en langbehaarde streep. De kleur van de vacht is aan den bovenkant en den onderkant ongeveer gelijk, aan den onderkant evenwel wat lichter. Overigens is de tint zeer ongelijk bij verschillende individu's: zij varieert van donkerzwart tot grijsbruin en licht aardkleurig grijs; sommige exemplaren zijn meer of min rossig.

Doordat de verschillende exemplaren zoo uiteenloopen èn in kleur van de vacht èn in grootte, hebben verschillende schrijvers dez onderscheidt reeds LinNaEus in plaats van ééne soort er drie: amphibius, paludosus en terrestris. Van deze heeft hij echter de eerstgenoemde soort (amphibilus) zelf niet gezien. WILLUGBY had het dier levend waargenomen, zijn groot zwemvermogen bewonderd en in eene nagelaten aanteekening zwemvliezen vermeld: misschien omdat hij zonder meer aannam dat een zoo goed zwemmend dier noodzakelijker wijze ook zwemvliezen moest hebben; misschien ook omdat hij van plan was, later andere exemplaren, die hij in zijn bezit mocht krijgen, op de aanwezigheid van zwemvliezen te onderzoeken. LiNNaEus nu heeft in zijn werk den amphibius van WILLUGBY "met zwemvliezen" opgenomen, maar hij voegde er dadelijk bij dat hij het dier niet zelf heeft gezien, en vermoedde reeds dat amphibius niet van zijne soort terrestris verschillend zou zijn. De paludosus van LINNAEUS is door den grooten $Z$ weed zelven gezien; het is eene zwarte variëteit met witte voeten.

De Selys-Longchamps („Etudes de Micromammalogie”) onderscheidt 4 soorten: Arvicola amphibius, destructor, monticola en terrestris; en van ieder dezer soorten geeft hij de geografische 
verbreiding op. Andere schrijuers hebben weer andere soorten opgesteld. De zaak is echter deze: dat al deze schrijvers blijkbaar hunne verschillende soortdiagnosen hebben samengesteld naar een grooter of kleiner, maar in ieder geval naar een vrij beperkt getal objecten, uit de eene of andere streek ontvangen.

Wie uit ééne en dezelfde streek groote menigten woelratten met elkander vergelijkt, - ik ontving er sedert jaren een zeer groot aantal uit Aalsmeer en van den Langendijk, - die komt tot de conclusie, dat reeds in die ééne streek de variatie in kleur, grootte en relatieve staartlengte en vorm van den schedel bijzonder groot is; zeker even groot als de verschillen, die er - volgens de beschrijving van de Selys Longchamps bestaan tusschen de vormen, welke hij uit onderscheiden streken van Europa en van Azië ontving. Zoo is volgens dezen zoöloog Arvicola amphibius an de rugzijde donker aardbruin, aan de buikzijde donkergrijs en langstaartig; Anicola destructor aan de rugzijde donkergeelachtig bruin, aan de buikzijde witachtig grijs, cveneens langstaartig; Arvicola monticola aan de rugzijde licht geelachtig grijs, aan de buikzijde witachtig grijs, kortstaartig; Arvicola terrestris tamelijk licht van kleur, aan den bovenkant geelachtig bruin, aan den onderkant geelachtig grijs van kleur en kortstaartig. Maar al de vormen, door de Selys LovGchimps beschreven, komen door elkander voor, zoowel aan den Langendijk als te Aalsmeer.

Nog in 1879 schreef ik in mijne "Landbouwdierkunde" (deel I, bl. 124): "Het schijnt dat de verscheidenheid, die de hoogere zandgronden bewoont, in ons land niet voorkomt." Sinds dien ben ik met vele gevallen bekend geworden van het voorkomen van woelratten op hooge, droge gronden (bijv. in de Graafschap en op de Veluwe): in verscheiden streken is het dier daar bekend onder de namen "aardwolf" en "vreetwolf." Algemeen wordt in Duitsche werken vermeld, dat in de hoogere streken, ver van het water verwijderd, een vorm van 
de woelrat voorkomt, die iets kleiner is dan de gewone, lichter van kleur en meer kortstaartig. Die vorm wordt dan als eene afzonderlijke verscheidenheid aangeduid onder den naam Arvicola amphibius var. terrestris. Aanvankelijk, toen ik nog maar weinig exemplaren, van hoogere zandgronden afkomstig, onder de oogen had gehad, meende ik dat deze onderscheiding steek hield; maar later is mij gebleken, dat zij niet opgaat. Wel komt het mij voor, dat gemiddeld de exemplaren van den hoogen zandgrond iets kleiner zijn dan die van lage gronden en van den waterkant, wat met het verschil in voedsel zou kunnen in verband staan; maar ik heb toch nog te weinig "woelratten" van lage en van hooge gronden met elkander vergeleken, om met zekerheid omtrent de grootte der exemplaren van verschillende gronden een oordeel uit te spreken. Wèl kan ik met beslistheid verklaren, dat de "aardwolf" of "vreetwolf" van onzen diluvialen zandbodem bij lange na niet altijd lichter van kleur is dan de zoogenaamde "waterrat" van den Langendijk en van Aalsmeer. Evenwel hebben - naar het mij voorkomt - gemiddeld de donkere exemplaren wat langeren staart dan de lichtere. Soms komen in hetzelfde nest jongen van vrij uitéénloopende kleur voor: zwartachtig of roodachtig bruine met geelachtig grijze.

Het schijnt mij derhalve, dat men geen recht heeft, den ,aardof vreetwolf" onzer hoogere diluviale zandgronden te beschouwen als eene andere variëteit, nog minder als eene andere soort dan de "woelrat" of "waterrat" der lagere, alluviale landen.

WAGENINGEN, 1 April 1912.

(Wordt vervolgd.)

J. RITZEMA BOS. 


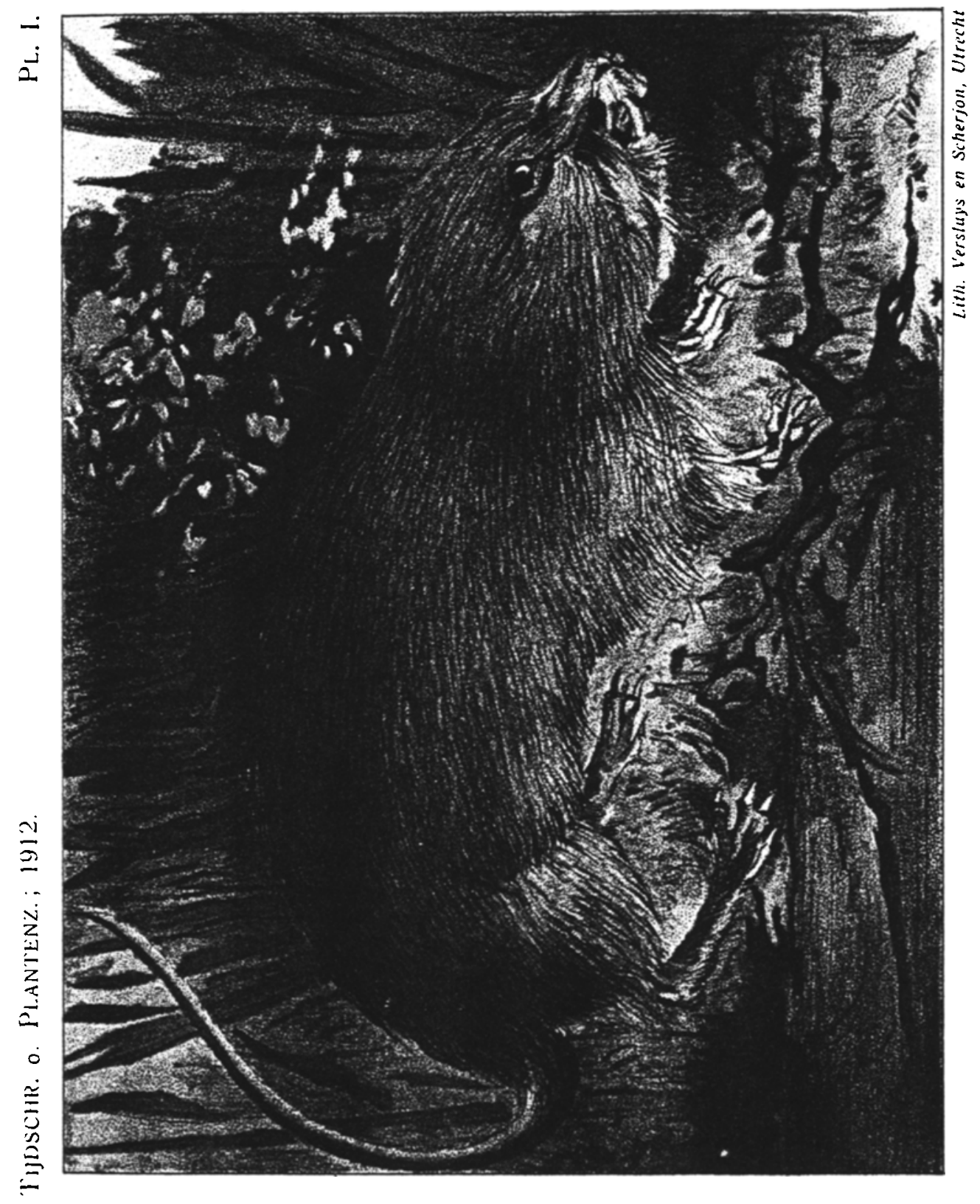

